\title{
REPRESENTAÇÕES SOCIAIS DE MASCULINIDADES EM MÚSICAS SERTANEJAS DE ARTISTAS FEMININAS.
}

\author{
AUTOR: FERNANDA MOREAU DE ALMEIDA SOARES \\ CO-AUTOR/ORIENTADOR: REBECA VALADAO BUSSINGER
}

Resumo: Este estudo tem como objetivo a análise de músicas sertanejas cantadas por mulheres lançadas no período de 2015 à 2019, coletadas nos rankings das 100 músicas mais tocadas em cada ano, segundo as bases de dados Crowley e Connectmix. A análise possibilitou a construção de categorias de temas figurativos referentes à representação de mulher e de masculinidades presentes no senso comum da sociedade brasileira. Investigou-se o desenvolvimento de uma subclasse do gênero musical sertanejo, o Feminejo, que têm como característica principal o protagonismo feminino. Foi constatado que as letras das canções do Feminejo promovem uma quebra de paradigma através da inserção de uma nova representação social de mulher, constituída com aspectos relativos tanto à representação social hegemônica de mulher quanto às representações sociais de masculinidades. Em suma, este tensionamento constitui uma espécie de estratégia comercial para a ascensão e estabilização das mulheres no mercado da música sertaneja, e pode ser uma explicação para cantoras mais tradicionais - que optam por seguir a linha da representação hegemônica - não conseguirem mais se manter no topo das paradas.

Palavras-chave: Gênero, Mulher, Masculinidades, Feminejo, Representações Sociais. 